\title{
Analisis Kebijakan Pemerintah Purwakarta tentang Pendidikan Karakter Berbasis Kearifan Lokal di Kabupaten Purwakarta
}

\author{
HELMI AZIZ \\ Program Studi Pendidikan Agama Islam, Universitas Islam Bandung \\ Jln. Ranggagading No. 8 Kota Bandung \\ E-mail: helmiaziz87@gmail.com
}

Article Received: 17-07-2018

Published Article: 07-11-2018

DOI: https://doi.org/10.29313/ga.v2i1.4167

\begin{abstract}
The gap between the community and the world of education requires educational reform from time to time without stopping, which is directed at strengthening local values. The purpose of this study was to analyze the regent of Purwakarta's policy regarding the application of local culture-based character education in Purwakarta Regency and analyze the social impact of the application of local culture-based education in Purwakarta Regency. The research method used is content analysis with a qualitative approach. The results showed that the application of Purwakarta regent's policy on local culture-based character education in Purwakarta Regency that was applied in formal educational institutions with special seven-day programs that were well programmed through formal education institutions was able to shape students' character and student life skills.
\end{abstract}

Keywords: Policy, Character Education, and Local Culture.

\begin{abstract}
Abstrak
Adanya kesenjangan antara masyarakat dengan dunia pendidikan memerlukan reformasi pendidikan dari waktu ke waktu tanpa henti, yang diarahkan pada penguatan nilai-nilai lokal. Tujuan dari penelitian ini adalah untuk menganalisis kebijakan bupati purwakarta mengenai penerapan pendidikan karakter berbasis kearifan lokal di Kabupaten Purwakarta, dan menganalisis dampak sosial penerapan pendidikan berbasis kearifan lokal di Kabupaten Purwakarta. Metode penelitian yang digunakan adalah content analysis dengan pendekatan kualitatif. Hasil penelitian menunjukkan bahwa penerapan kebijakan bupati Purwakarta tentang pendidikan karakter berbasis kearifan lokal di Kabupaten Purwakarta yang diterapkan dalam lembaga pendidikan formal dengan program tujuh hari istimewa yang terprogram dengan baik melalui lembaga pendidikan formal, mampu membentuk karakter siswa dan kecakapan hidup siswa.
\end{abstract}

Kata Kunci: Kebijakan, Pendidikan karakter, dan Kearifan Lokal.

\section{Pendahuluan}

Menurut para ahli sosiologi pendidikan, terdapat relasi resiprokal (timbal balik) antara dunia pendidikan dengan kondisi sosial masyarakat. Relasi ini bermakna bahwa apa yang berlangsung dalam dunia pendidikan merupakan gambaran dari kondisi yang sesungguhnya di dalam kehidupan masyarakat yang kompleks. Demikian juga sebaliknya, kondisi masyarakat, baik dalam aspek kemajuan, peradaban dan sejenisnya, tercermin dalam kondisi dunia pendidikannya. Oleh karena itu, majunya dunia pendidikan dapat dijadikan cermin majunya masyarakat, dan dunia pendidikan yang amburadul juga dapat menjadi cermin terhadap kondisi masyarakatnya yang penuh persoalan (Naim dan Sauqi, 2008: 13).

Ketika pendidikan dijadikan sebagai cerminan kondisi sosial masyarakatnya, maka penerapan pendidikan perlu disesuaikan dengan keadaan atau kebutuhan masyarakat 
sekitar dan lebih luas lagi masyarakat global. Akan tetapi kenyataannya dunia pendidikan saat ini dilanda kegelisahan khususnya di Indonesia, dimana sistem pendidikan nasional yang telah dibangun selama tiga dasawarsa terakhir, ternyata belum mampu sepenuhnya menjawab kebutuhan, tantangan nasional dan globalisasi dewasa ini (Suyanto dan Djihad Hasyim, 2000: 2).

Kondisi saat ini, dunia pendidikan harus berhadapan dengan setumpuk persoalan yang kompleks, baik persoalan dari dunia pendidikan sendiri maupun persoalan di luar dunia pendidikan; rendahnya penyerapan lulusan di lapangan kerja, minimnya kreativitas manusia produk pendidikan, tawuran antarpelajar, siswa terlibat narkoba dan berbagai macam bentuk perilaku kekerasan (Nata, 2003:

1). Semuanya merupakan bukti adanya kesenjangan antara masyarakat dengan dunia pendidikan. Kesenjangan ini merupakan realitas yang menjadi tantangan tersendiri bagi dunia pendidikan.

Perlu adanya reformasi pendidikan dari waktu ke waktu tanpa henti, yang berpegang pada tantangan masa depan yang penuh dengan persaingan global. Salah satu dari reformasi dalam bidang pendidikan yaitu diarahkan pada penguatan nilai-nilai lokal (kearifan lokal, lokal value), baik yang bersifat geografis, teritorial maupun yang bersifat capacity intelectual. Hal ini sebagai bagian dari upaya optimalisasi potensi domestik, baik yang bersifat kultur, regional, lokal maupun menciptakan keunggulan personal yang memiliki kearifan intelektual, emosional dan spiritual, sehingga dapat membentuk generasi muda yang sesuai dengan tata nilai: cageur, bageur, bener, pinter jeung singer. Konsep pendidikan berbasis kearifan lokal tersebut diterapkan di Kabupaten Purwakarta.

Berkenaan dengan latar belakang tersebut, maka dipandang perlu pembahasan tentang Analisis Kebijakan Pemerintah Kabupaten Purwakarta Mengenai Penerapan Pendidikan Karakter Berbasis Kearifan Lokal di Kabupaten Purwakarta. Kajian penelitian terdahulu menyebutkan bahwa penerapan program tujuh poe atikan pendidikan Purwakarta istimewa melalui metode pembiasaan dengan pendekatan tematik dan holistic mampu membentuk karakter siswa ke arah yang lebih baik (Millah, 2018: 1). Hal senada diungkapkan oleh Hayani Wulandari (Jurnal Pendidikan ke-SD-an, Vol 13 No 1, 2017: 13-14) yang menyimpulkan bahwa melalui program Atikan Purwakarta dapat menumbuhkan berbagai pendidikan karakter bagi anak usia dini. Penelitian yang dilakukan oleh Nur Afriani (Skripsi, 2017: 1) yang terfokus pada evaluasi kebijakan peraturan bupati Purwakarta No 69 tahun 2015 tentang pendidikan karakter menyimpulkan bahwa kebijakan tersebut masih memiliki kelemahan antara lain dampak kekurangan tidur pada peserta didik secara signifikan dapat berpengaruh pada prestasi akademis yang rendah, ditambah dengan banyaknya kontra dan kritikan dari masyarakat sehingga kebijakan tersebut memerlukan kajian ulang yang melibatkan pelaku pendidikan dan ahli pendidikan.

Bagaimanapun, berdasarkan kajian terdahulu tersebut belum ada yang membahas dampak sosial dari penerapan pendidikan kearifan lokal di Kabupaten Purwakarta bagi perkembangan karakter peserta didik. Tujuan dari penelitian ini adalah untuk menganalisis kebijakan bupati purwakarta mengenai penerapan pendidikan berbasis kearifan lokal di Kabupaten Purwakarta; dan menganalisis dampak sosial penerapan pendidikan berbasis kearifan lokal di Kabupaten Purwakarta.

\section{Metode Penelitian}

Pendekatan penelitian yang digunakan dalam penelitian ini adalah pendekatan kualitatif. Adapun metode yang digunakan yaitu metode penelitian content analysis. Content analysis digunakan untuk menelaah isi dari suatu dokumen. Dokumen dalam penelitian ini yaitu Kebijakan Peraturan Bupati Purwakarta Nomor 69 Tahun 2015 tentang Pendidikan Berkarakter. Adapun hal-hal yang akan dideskripsikan dalam penelitian ini yaitu program pendidikan karakter "tujuh poe atikan pendidikan Purwakarta istimewa". Teknik pengumpulan data yang digunakan dalam penelitian ini yaitu analisis dokumen yang dimulai dari tahap pembacaan, pencatatan dokumen hingga analisis dokumen.

\section{Pendidikan Karakter Berbasis Keari- fan Lokal}

Kearifan lokal dalam bahasa asing sering dikonsepsikan sebagai kebijakan setempat (lokal wisdom), pengetahuan setempat (lokal knowledge) atau kecerdasan setempat (lokal genious). Kearifan lokal juga dapat dimaknai sebuah pemikiran tentang hidup. Pemikiran tersebut dilandasi nalar jernih, budi yang baik, dan memuat hal-hal positif. Kearifan lokal dapat diterjemahkan sebagai karya akal budi, perasaan mendalam, 
tabiat, bentuk perangai, dan anjuran untuk kemuliaan manusia. Penguasaan atas kearifan lokal akan mengusung jiwa mereka semakin berbudi luhur (Wagiran, 2012: 330).

Nasrudin menyebutkan bahwa kearifan lokal merupakan perwujudan dari daya tahan dan daya tumbuh yang dimanifestasikan melalui pandangan hidup, pengetahuan, dan pelbagai strategi kehidupan yang berupa aktivitas yang dilakukan oleh masyarakat lokal untuk menjawab berbagai masalah dalam pemenuhan kebutuhan hidupnya, sekaligus memelihara kebudayaannya. Dalam pengertian inilah kearifan lokal sebagai jawaban untuk bertahan dan menumbuhkan secara berkelanjutan kebudayaan yang didukungnya (Nasrudin, 2011: ix).

Definisi kearifan lokal tersebut, paling tidak menyiratkan beberapa konsep, yaitu: (1) kearifan lokal adalah sebuah pengalaman panjang, yang diendapkan sebagai petunjuk perilaku seseorang; (2) kearifan lokal tidak lepas dari lingkungan pemiliknya; dan (3) kearifan lokal itu bersifat dinamis, lentur, terbuka, dan senantiasa menyesuaikan dengan zamannya. Konsep demikian juga sekaligus memberikan gambaran bahwa kearifan lokal selalu terkait dengan kehidupan manusia dan lingkungannya. Kearifan lokal muncul sebagai penjaga atau penyaring iklim global yang melanda kehidupan manusia. Kearifan adalah proses dan produk budaya manusia, dimanfaatkan untuk mempertahankan hidup (Wahyuni, tt: 118).

Berdasarkan definisi mengenai kearifan lokal tersebut, dapat diketahui bahwa terdapat signifikansi serta fungsi kearifan lokal sebagaimana yang dikemukakan John Haba sebagaimana dikutip Irwan Abdullah dkk, yaitu sebagai berikut:

Pertama, Sebagai penanda identitas sebuah komunitas yang membedakannya dengan komunitas lain.

Kedua, Menjadi elemen perekat lintas warga, lintas agama dan kepercayaan. Kearifan lokal dianggap mampu mempersatukan perbedaan yang ada di masyarakat.

Ketiga, Kearifan lokal tidak bersifat memaksa, tetapi ada dan hidup bersama masyarakat. Kesadaran diri dan ketulusan menjadi kunci dalam menerima dan mengikuti kearifan lokal.

Keempat, Kearifan lokal memberikan warna kebersamaan dalam komunitas. Tentu saja kebersamaan yang harmonis atas dasar kesadaran diri.
Kelima, Kearifan lokal mampu mengubah pola pikir dan hubungan timbalbalik individu dan kelompok. Proses interaksi dalam komunitas telah berpengaruh terhadap pola perilaku individunya, dan

Keenam, Kearifan lokal dapat berfungsi mendorong terbangunnya apresiasi sekaligus menjadi sebuah mekanisme bersama untuk menepis berbagai kemungkinan yang meredusir atau bahkan merusak solidaritas (Abdullah, dkk, 2008: 7-8).

Kesimpulannya, kearifan lokal yang terprogram dengan baik, melalui proses pembiasaan dapat menjadi pedoman hidup masyarakat dewasa ini. Nilai-nilai kearifan lokal dapat digunakan untuk menyaring nilai-nilai baru yang berkembang secara cepat sebagai akibat dari perkembangan ilmu pengetahuan dan teknologi agar tidak bertentangan dengan nilai-nilai Ilahi dan kemanusiaan. Sehingga dapat menjadi benteng yang kokoh dalam menghadapi modernitas sehingga nilai-nilai tradisi lokal yang telah mengakar dapat terpelihara dengan baik.

Berkaitan dengan pendidikan berbasis kearifan lokal, menurut Anna Sri Maluppi mendefinisikan pendidikan berbasis kearifan lokal dalam tataran aplikasi adalah pendidikan yang mengajarkan peserta didik untuk selalu dekat dengan situasi konkrit yang mereka hadapi sehari-hari. Model pendidikan berbasis kearifan lokal merupakan sebuah contoh pendidikan yang mempunyai relevansi tinggi bagi kecakapan pengembangan hidup, dengan berpijak pada pemberdayaan keterampilan serta potensi lokal pada tiap-tiap daerah (2011). Oleh sebab itu, pendidikan formal saat ini perlu didorong untuk kembali kepada makna, esensi, dan filosofi pendidikan nasional yang menginginkan pendidikan itu berakar pada nilai agama dan kebudayaan nasional (Helmi Aziz, 2016: 23).

Begitu besar peranan kebudayaan dalam pendidikan, atau dengan kata lain pendidikan tidak dapat dilepaskan dari kebudayaan. Untuk lebih jelas dalam membahas permasalahan kebudayaan dalam pendidikan, model yang tepat adalah konsep Taman Siswa Ki Hadjar Dewantara. Beliau telah meletakan dasar-dasar pendidikan yang berorientasi budaya. Ini terlihat dari asas -asas Taman Siswa yang dikenal dengan Pancadharma yakni kodrat alam, kemerdekaan, kebangsaan, kebudayaan dan kemanusiaan.

Asas kodrat alam mengandung arti bahwa manusia adalah bagian dari alam 
semesta, maka harus bersatu dengan alam. Asas kemerdekaan mengandung arti kehidupan yang sarat dengan ketertiban dan kedamaian. Asas kebudayaan berarti memelihara nilai-nilai kebudayaan nasional. Asas kebangsaan berarti harus merasa satu dengan bangsanya. Dan asas kemanusiaan berarti tidak boleh ada permusuhan dan melalui akal budi mampu menimbulkan cinta kasih pada sesama manusia (H.A.R. Tilaar, 2002: 68).

Pendidikan kearifan lokal, selain mampu membentuk karakter siswa, juga mampu mengembangkan kecakapan hidup siswa. Upaya pengembangan pendidikan kearifan lokal tidak akan terselenggara dengan baik tanpa peran serta masyarakat secara optimal. Keikutsertaan berbagai unsur masyarakat dalam mengambil prakarsa dan menjadi penyelenggara program pendidikan merupakan kontribusi yang sangat berharga, yang perlu mendapat perhatian dan apresiasi.

\section{Hasil Penelitian dan Pembahasan}

Kebijakan Pemerintah Kabupaten Purwakarta Mengenai Penerapan Pendidikan Berbasis Kearifan Lokal di Kabupaten Purwakarta

Pembangunan di Kabupaten Purwakarta dewasa ini menuntut perhatian lebih, tidak hanya untuk menghadapi permasalahan yang belum terselesaikan, namun juga untuk mengantisipasi perubahan yang muncul di masa yang akan datang. Posisi Kabupaten Purwakarta yang strategis sebagai "Gerbang Pasundan" dan berdekatan dengan ibukota negara, mendorong Kabupaten Purwakarta untuk berperan serta secara aktif sebagai agent of development (agen pembangunan) bagi pertumbuhan nasional.

\begin{abstract}
Tantangan perubahan kompetisi global yang dinamis, menuntut Kabupaten Purwakarta untuk mengimbanginya, agar dapat seiring dan sejalan dalam gerak langkah terpadu, guna memberikan pilihan yang dibutuhkan oleh masyarakat. Sehingga mampu meningkatkan kesejahteraan masyarakat (social welfare). Oleh karenanya eksistensi pembangunan daerah didedikasikan untuk membangun kompetensi daerah yang berdaya saing dengan memanfaatkan potensi sumberdaya yang dimiliki, yaitu meliputi sumber daya manusia, daya dukung alam, dan potensi sosial kemasyarakatan.
\end{abstract}

Arah kebijakan pembangunan daerah berorientasi pada keunggulan pendidikan, kesehatan, pertanian, industri, perdagangan dan jasa, serta pengembangan infrastruktur wilayah yang berbasis religi dan nilai-nilai kearifan lokal. Disamping itu, pembangunan tersebut dilaksanakan dengan tanpa mengesampingkan peningkatan keutuhan lingkungan baik hulu maupun hilir, fisik dan sosial.

Guna menuju kearah tersebut, pemerintahan daerah dituntut agar lebih mandiri, inovatif dan kreatif dengan mengembangkan struktur pemerintahan efektif yang berorientasi kepada kepuasan pelayanan publik, serta dapat mengembangkan potensi kewirausahaan birokrasi yang berorientasi pada kemakmuran rakyat. Sehingga jarak antara pemerintah dan masyarakat menjadi semakin dekat dan kinerja pelayanan public (public services) menjadi lebih baik. Dengan demikian, akselerasi pembangunan dan ekonomi daerah dalam rangka meningkatkan kesejahteraan masyarakat akan dapat tercapai.

Dengan mempertimbangkan potensi, kondisi, permasalahan, tantangan dan peluang yang ada di Kabupaten Purwakarta serta budaya yang hidup dalam masyarakat, telah disusun Visi dan Misi Pemerintah Daerah Kabupaten Purwakarta. Visi dan Misi tersebut ditetapkan dengan Peraturan Daerah Kabupaten Purwakarta Nomor 1 Tahun 2010 tentang Rencana Pembangunan Jangka Menengah Daerah.

\section{Visi dan Misi Kabupaten Purwakarta (Jangka Menengah)}

Rumusan Visi dan Misi didasarkan atas inspirasi dan analisis terhadap lingkungan serta isu strategis lokal Kabupaten Purwakarta. Gambaran lingkungan strategis dan isu strategis harus dapat disikapi secara proporsional berdasarkan potensi dan kemampuan daerah.

Berdasarkan pemikiran dan tekad yang kuat untuk mewujudkan "Purwakarta Digjaya" serta didorong dengan itikad "Ngawujudkeun Purwakarta Nagri Raharja", berikut Visi dan Misi Pembangunan Kabupaten Purwakarta, sebagai arah utama pembangunan jangka menengah daerah:

\section{Visi Kabupaten Purwakarta}

Makna Visi Pembangunan: "Purwakarta Berkarakter" sesungguhnya secara 
sederhana merupakan pencerminan dari aspek kepribadian; ciri khas (branded); kumpulan peran; mandiri; berdaya saing; tangguh; serta maju sesuai dengan tata nilai masyarakat Purwakarta yang berlandaskan religi keislaman dan tata nilai lokal pilemburan (lokal values).

\section{Misi Kabupaten Purwakarta}

Makna dari Misi dalam upaya pencapaian Visi Purwakarta Berkarakter adalah Mengembangkan Pembangunan Berbasis Religi dan Kearifan Lokal, yang Berorientasi pada Keunggulan Pendidikan, Kesehatan, Pertanian, Industri, Perdagangan dan Jasa.

Untuk mewujudkan Visi Pembangunan: "Purwakarta Berkarakter" pada aspek kualitas sumber daya manusia dan tatanan kehidupan ekonomi masyarakat, maka Pemerintah Kabupaten Purwakarta mempunyai misi untuk senantiasa mengembangkan pembangunan berbasis religi dan kearifan lokal, yang berorientasi pada keunggulan pendidikan, kesehatan, pertanian, industri, perdagangan dan jasa. Pembangunan berbasis religi dan kearifan lokal yang berorientasi pada keunggulan pendidikan, kesehatan, pertanian, industri, perdagangan dan jasa. Dalam makalah ini hanya dikutip keunggulan di bidang pendidikan yaitu perlu dilakukannya penguatan nilai-nilai lokal (kearifan lokal, lokal value), baik yang bersifat geografis, teritorial maupun yang bersifat capacity-intelectual. Hal ini sebagai bagian dari upaya optimalisasi potensi domestik, baik yang bersifat kultur, regional, lokal maupun menciptakan keunggulan personal, yang memiliki kearifan intelektual, emosional dan spiritual, sehingga dapat membentuk generasi Purwakarta yang sesuai dengan tata nilai: cageur, bageur, bener, pinter, jeung singer (LKPJ Bupati Purwakarta Tahun 2012: 1-3).

Dalam mewujudkan misi tersebut, sistem pendidikan di Kab. Purwakarta sedang menerapkan program tujuh hari pendidikan Purwakarta istimewa. Program ini terdiri dari muatan berbagai aspek agar murid-murid bisa mengenal kearifan lokal.

Pertama, Hari pertama (hari senin) untuk program di atas dinamakan ajeg nusantara. Ajeg Nusantara merupakan momentum dalam mewujudkan generasi muda yang mengenal akan nusantaranya, dan memiliki rasa kebangsaan yang kuat sehingga melahirkan sikap nasionalisme yang kokoh ditengah-tengah ancaman negara lain yang ingin menghancurkan persatuan bangsa ini. Jadi guru akan mengajarkan muridnya seluruh mata pelajaran dikaitkan dengan berbagai hal yang ada di nusantara;

Kedua, Hari kedua (hari selasa), mapag di buana atau menjemput dunia. Maksudnya anak-anak akan diberikan pengetahuan tentang dunia internasional. Bahasa yang dipergunakan sebagai komunikasi di sekolah diharapkan menggunakan bahasa internasional;

Ketiga, Hari ketiga (hari rabu) maneuh di sunda, muatannya berisi pendidikan khas sunda. Langkah strategis yang digunakan yaitu siswa dan guru menggunakan pakaian sunda, pakaian tradisi pangsi/ kampret lengkap dengan iket untuk siswa dan guru laki-laki dan kebaya lengkap dengan samping kebat bagi siswi dan guru perempuan. Pada hari ketiga ini, guru mengenalkan nilai hidup orang sunda. Guru juga membahas tradisi sunda dari cara bercocok tanamnya, sistem pertanian yang digunakan, seni musik, seni karawitan, seni tari dan seni tradisi lainnya yang memperkaya budaya sunda;

Keempat, Hari keempat (hari kamis) diberi nama nyanding wawangi, hari khusus belajar estetika. Murid diberikan kebebasan berekspresi dalam mengembangkan daya rasa dan karsa untuk menggali potensi dan kreatifitasnya.;

Kelima, Hari kelima (hari jum'at) diberi nama nyucikeun diri, berarti mendekatkan hati, jiwa dan pikiran kepada Yang Maha Kuasa. Di hari jumat, berisi penanaman nilai spiritual dan kebersihan lingkungan. Selain itu, bagi yang beragama Islam, peserta didik dan pendidik diwajibkan memakai pakaian muslim/ muslimah; dan

Keenam, Hari keenam dan ketujuh (hari sabtu dan minggu) diberi nama betah di imah, merupakan pembiasaan yang memiliki nilai agar siswa dapat berinteraksi dan dekat dengan keluarganya (Sindonews. 17-9-2014).

Tujuh hari istimewa tersebut merupakan pelaksanaan pendidikan kearifan lokal pada aspek pengajaran dan pembelajaran kurikuler di setiap sekolah yang ada di kabupaten Purwakarta. 


\section{Dampak Sosial Penerapan Pendidi- kan Berbasis Kearifan Lokal di Kabu- paten Purwakarta}

Kearifan lokal merupakan sebuah kebenaran, yang diendapkan sebagai petunjuk perilaku seseorang yang bersifat dinamis dan berkembang sesuai dengan perkembangan zaman di suatu daerah. Kearifan lokal merupakan perpaduan antara nilai ketuhanan yang bersifat mutlak dengan nilai kemanusiaan yang bersifat dinamis. Kearifan lokal sebagai wujud keunggulan budaya daerah. Upaya untuk mengintegrasikan kearifan lokal di Kabupaten Purwakarta dengan desain pendidikan karakter di lembaga pendidikan formal, secara tidak langsung merupakan upaya untuk pembentukan karakter siswa dalam menyaring nilai-nilai yang baru atau asing yang cepat berkembang seiring perkembangan ilmu pengetahuan dan teknologi yang pesat. Selain itu, mampu membentuk anak dalam mendapatkan gambaran yang utuh atas identitas dirinya sebagai individu dan identitas dirinya sebagai anggota masyarakat yang terkait dengan budaya yang telah dipelihara sejak dahulu.

Menggali dan menanamkan kembali kearifan lokal secara inheren melalui pembelajaran, dapat dikatakan sebagai gerakan kembali pada basis nilai budaya daerahnya sendiri, sebagai bagian upaya membangun identitas bangsa dan sebagai semacam filter dalam menyeleksi pengaruh budaya "lain". Nilai-nilai kearifan lokal itu meniscayakan fungsi yang strategis bagi pembentukan karakter dan identitas bangsa. Pendidikan yang menaruh peduli terhadapnya, akan bermuara pada munculnya sikap yang mandiri, penuh inisiatif, santun dan kreatif.

Pada posisi ini, nilai yang terkandung dalam bingkai kearifan lokal sebuah daerah akan menjadi senjata yang ampuh untuk membangun karakter anak bangsa, agar memiliki jiwa nasionalisme yang tinggi sekaligus mampu menjadi penjaga kelestarian kearifan lokal tersebut melalui sikap keseharian yang berkarakter kuat. Uraian tersebut di atas menjadi sangat logis, karena diakui atau tidak nilai-nilai kearifan lokal yang notabene merupakan sedimentasi dari nilainilai kebaikan yang dianut di sebuah daerah, nantinya akan memberikan warna positif bagi pembangunan karakter anak. Ketika warna positif kearifan lokal dominan dalam proses pembangunan karakter anak, maka kearifan lokal tersebut akan mampu mendinamisasi perkembangan karakter anak menuju arah yang lebih baik di masa yang akan datang (Majalah El-Qudsy, Edisi 21 tahun 2013).

\section{Kesimpulan}

Kearifan lokal yang terprogram dengan baik, melalui proses pembiasaan dapat menjadi pedoman hidup masyarakat dewasa ini. Nilai-nilai kearifan lokal dapat digunakan untuk menyaring nilai-nilai baru yang berkembang secara cepat sebagai akibat dari perkembangan ilmu pengetahuan dan teknologi agar tidak bertentangan dengan nilai-nilai Ilahi dan kemanusiaan sehingga dapat menjadi benteng yang kokoh dalam menghadapi modernitas sehingga nilai-nilai tradisi lokal yang telah mengakar dapat terpelihara dengan baik.

Tujuh hari istimewa yang diterapkan di Kabupaten Purwakarta merupakan pelaksanaan pendidikan kearifan lokal pada aspek pengajaran dan pembelajaran kurikuler di setiap sekolah yang ada di kabupaten Purwakarta. Dengan program tujuh hari istimewa yang terprogram dengan baik melalui lembaga pendidikan formal, mampu membentuk karakter siswa dan kecakapan hidup siswa. Kearifan lokal di yang terprogram dengan baik di Kabupaten Purwakarta merupakan kekayaan budaya yang perlu diangkat kepermukaan sebagai bentuk jati diri bangsa. Lebih dari itu, kearifan lokal juga dapat dijadikan rujukan penyelesaian masalah bangsa.

\section{Daftar Pustaka}

Abudin Nata . (2003). Kapita Selekta Pendidikan Islam. Bandung: Angkasa.

Anna Sri Marlupi. (2011). Artikel Pendidikan Berbasis Kearifan Lokal. Semarang: Yayasan Pangudi Luhur.

H.A.R. Tilaar. (2002). Pendidikan, Kebudayaan, dan Masyarakat Madani Indonesia. Bandung: Remaja Rosdakarya. cet. III.

Hayani Wulandari. (2017). Menumbuhkan Pendidikan Karakter Melalui Atikan Purwakarta Pada Pendidikan Anak Usia Dini.Metodik Didaktik Jurnal Pendidikan ke-SD-an, Vol 13 No 1.

Helmi Aziz. (2016). Internalization of Character Education Based on Local Wisdom: Field Studies in Kampung Kahuripan/ Tajur Pasanggrahan Village of Purwakarta Regency. Jurnal Pendidikan Islam :: Volume 5, Number 1. 
Irwan Abdullah, dkk. (2008). Agama dan Kearifan Lokal dalam Tantangan Global. Yogyakarta: Pustaka Pelajar.

LKPJ Bupati Purwakarta Tahun 2012.

Majalah El-Qudsy, Edisi 21 tahun 2013

Miftah Auliya Hudatul Millah, (2018). Upaya Pembinaan Akhlak Siswa Melalui Program 7 (Tujuh) Poe Atikan Purwakarta Istimewa: Penelitian di SMPN 5 Raden Muhammad Shaleh Purwakarta. Bandung: UIN Sunan Gunung Djati.

Nasrudin, dkk. (2011). Buku Kearifan Lokal di Tengah Modernisasi. Jakarta: Pusat Penelitian dan Pengembangan Kebudayaan Badan Pengembangan Sumber Daya Kebudayaan dan Pariwisata kementerian Kebudayaan dan Pariwisata Republik Indonesia.

Ngainun Naim dan Acham Sauqi. (2008). Pendidikan Multikultural Konsep dan Aplikasi. Jogjakarta: Ar-Ruzz Media Group.

Nur Afrini, (2017). Evaluasi Kebijakan Peraturan Bupati Purwakarta Nomor 69 Tahun 2015 tentang Pendidikan Berkarakter. Skripsi, Yogyakarta: Universitas Muhammadiyah Yogyakarta.
Sindonews. 17-9-2014. Program Tujuh Hari Pendidikan Kearifan Lokal di Purwakarta. Jakarta: Sindonews.

Siti Wahyuni. tt. Jurnal Keberagaman Dan Makna Nilai Kearifan Lokal Sebagai Sumber Inspirasi Pembelajaran Seni Budaya Yang Berkarakter. Madiun: IKIP PGRI.

Suyanto dan Djihad Hasyim. (2000). Refleksi dan Reformasi Pendidikan di Indonesia Memasuki Millenium III. Yogyakarta: Adicita Karya Nusa.

Wagiran. (2012). Jurnal Pengembangan Karakter Berbasis Kearifan Lokal Hamemayu Hayuning Bawana (Identifikasi Nilai-nilai Karakter Berbasis Budaya). FT Universitas Negeri Yogyakarta: Jurnal Pendidikan Karakter. 
HELMI AZIZ, Analisis Kebijakan Pemerintah Purwakarta Tentang Pendidikan Karakter Berbasis.... 